\title{
Chapter 1 \\ Academic Integrity in Canada: Historical Perspectives and Current Trends
}

\author{
Sarah Elaine Eaton (D) and Julia Christensen Hughes (i)
}

\begin{abstract}
In this chapter we discuss the development of academic integrity in Canada. We begin by offering insights into how provincial and territorial educational governance and policy structures have affected academic integrity in Canada, compared to other countries, such as the United States. In particular, we discuss why it may not make sense for Canadian schools to try to adopt the American honour code model. We explore the evolution of higher education in Canada, highlighting the earliest incidents of academic misconduct on record as well as the development of academic integrity scholarship, focusing on significant contributions and its impact over time. In particular, we draw attention to the emergence of policies, practices, associations, and networks intended to help Canada's higher educational institutions develop and strengthen cultures of integrity. Following, we discuss how the academic integrity landscape has shifted, noting recent trends such as the rise of contract cheating. We conclude with a call to action for more enhanced support for academic integrity scholarship to support advocacy, policy, and practice.
\end{abstract}

Keywords Academic integrity • Academic misconduct • Academic dishonesty • Canada $\cdot$ History

\section{Introduction}

The purpose of this chapter is to provide a contextual background for understanding academic integrity in Canada. We begin with an overview of Canadian educational governance structures and historical developments that have influenced academic integrity policy and practice in this country. Because some of the seminal research on academic integrity originated within the United States, and since we share a

\footnotetext{
S. E. Eaton $(\bowtie)$

University of Calgary, Calgary, Alberta, Canada

e-mail: seaton@ucalgary.ca

J. Christensen Hughes $(\varangle)$

Yorkville University, Toronto, Ontario, Canada

e-mail: jchristensen@yorkvilleu.ca

S. E. Eaton and J. Christensen Hughes (eds.), Academic Integrity in Canada, Ethics and Integrity in Educational Contexts 1 , https://doi.org/10.1007/978-3-030-83255-1_1
} 
border, it is important to be aware of similarities and differences between Canadian and US contexts and explore how the two countries differ in their approaches to education and, by extension, their approaches to academic integrity. We begin with a brief overview of Canada's educational governance model and present statistics with respect to both participation rates and performance measures. Then we examine the development of education from the 1600s up to Confederation, identifying key similarities and differences with our US neighbours during this time. We also point out key moments in the evolution of academic integrity. From there we explore the period from Confederation to World War II, as this was a major period of development in Canadian education (Gilbert et al., 1985; Jones, 2014). Following that, we examine what has happened in the post-war decades and examine current trends in the twentyfirst century.

In many ways, Canada shares more in common with other Commonwealth nations than it does with the United States, at least in terms of education. In this introductory chapter, we consider questions pertaining to particular characteristics of Canadian academic integrity culture, such as how Canada has built an honour culture without the formalized honour code system that exists in the US. We offer insights into how educational governance and policy structures affect academic integrity and consider possible transferability of lessons learned to other contexts. We conclude by calling for greater support for academic integrity scholarship, recognizing its importance to the future of education in Canada and beyond. In short, this chapter is about the unique aspects of academic integrity culture in Canada and its broader implications.

\section{Educational Governance and Structures in Canada}

Education in Canada is governed through a decentralized structure. There is no federal ministry or unified national system of education (Eaton, 2019b; Jones, 2014). Each of Canada's ten (10) provinces and three (3) territories is responsible for the funding and oversight of primary and secondary (often called "Kindergarten-Grade 12" or "K-12") and higher education. Canadian K-12 education is largely governed through ministries of education and legislative acts that are implemented by district school boards.

In Canada, the term higher education is often used inclusively to encompass various forms of post-secondary or tertiary education, including universities, colleges, community colleges, and CEGEPs (Canadian Society for the Study of Higher Education/Société canadienne pour l'étude de l'enseignement supérieur, 2020). CEGEPs (Collège d'enseignement général et professionnel or College of General and Vocation Education) are publicly-funded institutions unique to the province of Quebec that offer pre-university, technical, and short-duration programs (Féderacion des cégeps, n.d.).

Higher education institutions across the country offer programs in either of Canada's official languages, English or French. Some institutions offer programming in both languages, but most focus on a single language of instruction. As of 
2020, Canada had over 160 recognized public and private universities (including theological schools) and over 180 public colleges and institutes (Council of Ministers of Education Canada [CMEC], 2020). According to the most recent available statistics, enrollment in higher education institutions exceeds 2.1 million, including Canadian domestic and international students (Statistics Canada, 2019).

In reflecting on the characteristics of education in Canada, Glen Jones (2014) has pointed out that:

In some important respects higher education in Canada is the story of a network of institutions that break all the rules in terms of accepted norms of organizational theory and system design. There is no national 'system', no national ministry of higher education, no national higher education policy and no national quality assessment or accreditation mechanisms for institutions of higher education. (Jones, 2014, p. 1)

Quality assurance for higher education is the primary responsibility of the provinces and territories (Thacker \& McKenzie, 2022), although a common body provides oversight in the provinces of New Brunswick, Nova Scotia, and Prince Edward Island (see Maritime Provinces Higher Education Commission, n.d.).

Networks and associations of various kinds also play important roles. At the national level, for example, Universities Canada (2019), founded in 1911, represents the interests of publicly-funded universities across the country. Similarly, Colleges and Institutes Canada (n.d.) "is the national, voluntary membership organization representing publicly supported colleges, institutes, cegeps and polytechnics in Canada and internationally." Although these national associations do not have a regulatory function and nor do they provide quality assurance oversight, they provide opportunities for collaboration, strategic planning, and advocacy.

Collaboration among higher education institutions also occurs at the provincial and territorial level. For example, the purpose of the Council of Ontario Universities (COU, 2019) is to provide "a forum for Ontario's universities to collaborate and advocate in support of their shared mission to the benefit and prosperity of students, communities and the province of Ontario". Similarly, Colleges Ontario (2019) advocates for the province's twenty-four colleges. Other provinces have similar bodies that collaborate at the regional level.

Participation rates in higher education in Canada are high and growing, particularly within the university sector. According to Statistics Canada (2020):

The participation rate of Canadians aged 18 to 24 in university or college was up by $29 \%$ from the 2000/2001 to the 2018/2019 academic years. This increase was attributable to a larger share of young Canadians going to university $(+56 \%)$, as the participation rate at the college level was relatively stable. (n.p.)

In comparison with other OECD countries, Canada typically ranks amongst the highest; "In 2019, 63\% of 25-34 year-olds had a tertiary degree in Canada, compared to $45 \%$ on average across OECD countries" (Organisation for Economic Co-operation and Development [OECD], 2020, n.p.), with Canadian women participating at higher rates than their male counterparts (71\% vs. 55\%) (OECD, 2020). 


\section{Early Development of Higher Education and Academic Integrity in Canada and the United States (1600-1867)}

Canadian higher education institutions were developed under the models used in either Britain or France, with religious education (e.g., Roman Catholic, Presbyterian, Baptist, and Methodist) being a major influence throughout the 1700 and 1800s (Jones, 2014). Quebec was the first province to introduce higher education programs in the mid-1600s, through a Jesuit college (Jones, 2014). The British colonial legislatures, which later developed into provincial legislatures, followed suit shortly thereafter, founding the first English-speaking colleges in the early 1700s (Jones, 2014).

In the United States, the period from 1760 to 1860 was known as the Antebellum Period (Bertram Gallant, 2008; Lucas, 2006). This was a time when pedagogy was routinized, relationships between faculty and students became adversarial and educational institutions began to implement a system of grading to rank students (Allmendinger, 1973; Bertram Gallant, 2008). There is no parallel or specific title to describe the development of higher education during the same time period in Canada; it is important to note that education at all levels was developing in quite different ways in both countries throughout the sixteenth and seventeenth centuries.

Canada and the United States may have initially shared commonalities in the structure and approach of higher education (Jones, 2014), but the American Revolution resulted in a bifurcation of approaches that eventually led to quite different educational trajectories of the two countries. The American Revolution served as a catalyst for English-language higher education in Canada. Then British loyalists migrated north, and in doing so, dedicated life in their new country to strengthening British culture, including higher education (Jones, 2014). In contrast, the Constitution in the United States provided for a more open approach to education (Fishman, 2016; Lytton, 1996). That set the stage for more entrepreneurial approaches to higher education south of the border, with for-profit colleges emerging in the United States during the period of the American Revolution, in the late 1700s (Angulo, 2016). As a result, higher education in Canada developed in ways that made it more comparable to that of its Commonwealth cousins than to the United States.

Meanwhile in Canada, the first English-speaking colleges were opening around the same time, though under the careful watch of colonial legislatures for Englishspeaking institutions, while the Roman Catholic Church continued to play a significant role in Quebec, in particular (Jones, 2014). Over time, tensions between politicians and religious bodies about who should oversee education began to develop. These tensions continued throughout the first half of the seventeenth century in Canada. As a result, the period from 1800 to 1850 marked the half century where the trajectory of development for Canadian and American higher education systems began to diverge in ways that would result in drastic differences over time. Particular decisions of the two countries' respective governments and court systems solidified these diverging trajectories. 
Tensions over secular versus religious-based education led to King's College at York developing into the University of Toronto in 1849, establishing it firmly as Canada's first official secular university. The establishment of the University of Toronto was a significant turning point in the country's educational history in terms of the development of higher education, however, Canada was trailing behind the United States by almost 200 years. Harvard University was founded almost two centuries prior in 1636 (Harvard University, 2020).

In 1819, the US Supreme Court made a landmark decision in Dartmouth College v. Woodward, allowing for private colleges to flourish (Angulo, 2016). As a result, by the mid-nineteenth century there were already hundreds of thousands of students enrolled in for-profit colleges in the United States, with little quality assurance oversight, which led to concerns around degree and credential fraud (Angulo, 2016). By the mid-1800's, Canada's approach to higher education was already fundamentally different to that of the United States. Little is known about Canada's approach to academic integrity from 1600 to 1867 , but due to differences between the development of education in Canada and the United States during this period, it should not be assumed that matters relating to assessment, student conduct, and academic integrity were identical.

\section{Confederation to World War II (1867-1949)}

Canadian education scholars have identified the period from Confederation to World War II as being a major period of development in the country's educational systems (Gilbert et al., 1985; Jones, 2014). The Dominion of Canada was created under the British North American (BNA) Act of 1867, resulting in the confederation of the existing provinces of the time, which were Ontario, Quebec, New Brunswick, and Nova Scotia. Other provinces and territories joined later. The constitution established two levels of government: federal and provincial, with different responsibilities being assigned to each level. Education was assigned as a provincial, rather than a federal, responsibility (Jones, 2014). Even though the BNA Act of 1867 assigned responsibility for education to the government oversight of the provinces, ideological and political tensions arose over the role of religious bodies, who fought to maintain control over education.

Because the BNA Act of 1867 was pivotal in establishing education at all levels as a provincial responsibility, the period following resulted in rapid developments that had long-lasting effects. There were, however, exceptions to the federal government's abstention from intervening in matters of education. Within the first few years of education being deemed a provincial responsibility, the federal government undertook two major educational initiatives that have had an impact to the present day: the establishment of the Royal Military College of Canada (RMC) at the higher education level and, concurrently, the introduction of Indian Residential Schools for children. Both of these educational initiatives were launched in the 1870 s with funding and oversight from the federal government. 
The Royal Military College of Canada (RMC) was founded in Kingston, Ontario, in 1874, and was one of the only educational initiatives undertaken by the federal government (Cameron, 1991; Jones, 2014; Royal Military College of Canada, 2016). Originally named the Military College of Canada, the school was championed by then Prime Minister Alexander MacKenzie (Royal Military College of Canada, 2016). The rationale for this intervention into education was that it was a matter of the federal government's constitutional responsibility for defence (Cameron, 1991; Jones, 2014). The school accepted its first students in June 1876 and two years later, Her Majesty, Queen Victoria, granted the college the right to use the prefix "Royal" in its name, an honour the school maintains today (Royal Military College of Canada, 2016). The school's first programs were focused on military tactics, engineering, and other skills connected with the profession (Royal Military College of Canada, 2016). The school was granted the right to confer degrees in 1959.

As the federal government was planning for the education of its military personnel, it was concurrently planning for the establishment of Indian Residential Schools. The Indian Act of 1876 was formally amended in 1884 to provide for the establishment of Indian Residential Schools, whose stated purpose was to assimilate Indigenous children and "civilize the Indians" (Union of Ontario Indians, 2013, p. 3). The Government of Canada oversaw and funded the residential school system, with the collaboration of the Roman Catholic, Anglican, Methodist, Presbyterian, and United Churches, among others (Union of Ontario Indians, 2013, p. 3). Although various religious groups may have rivaled one another and opposed secular educational initiatives for control of higher education, they were united in their commitment to assimilate Indigenous children into European beliefs and behaviours.

Treatment of students at Indian Residential Schools has been documented as being excessively and horrifyingly punitive (Union of Ontario Indians, 2013, p. 6), with rule compliance being demanded at all times. Failure to comply resulted in punishments including beatings with fists and leather straps, burning and scalding of hands, and solitary confinement in closets, cages, and basements (Union of Ontario Indians, 2013). The impact of Indian Residential Schools was devastating and traumatic for Indigenous peoples (Union of Ontario Indians, 2013). The last residential school only closed in 1996 (Union of Ontario Indians, 2013) (Lindstrom, 2022; Poitras Pratt $\&$ Gladue, 2022). Today, the federal government continues to fund the education of primary and secondary education of "registered Indians living on reserves and the Inuit" (CMEC, 2001, p. 6), as well as Canadian Armed Forces members and incarcerated inmates.

Not long after the turn of the twentieth century, the development of networks and associations and conferences provided an opportunity for educators and administrators to share knowledge and work collectively. Concurrently, matters relating to student conduct have been documented as being of importance. The National Conference of Canadian Universities (NCCU) was launched in 1911, the same year Universities Canada was founded, providing an opportunity for university administrators to address common problems; they met twenty times between 1911 and 1944 (University of Manitoba, n.d.). Monohan (1971) documents how the issue of student conduct became a topic of concern during a 1922 conference, when participants: 
Heard an account of Dean Fox of Western of a case of a young lady recently expelled from a University for theft who was subsequently admitted in good faith by another University where her previous exploits were unknown. He moved the following resolution, which was adopted by the delegates, 'that this conference agree to the establishment of some sort of informal yet binding agreement by which each University will inform fully all the other Universities of the circumstances surrounding the expulsion of any student for a serious offense.' 'Serious' is not defined. Nor is it clear how the resolution was implemented. (Monohan, 1971, p. 36)

Although this matter pertained to what would be termed today as "non-academic misconduct", the division between academic and non-academic misconduct has been blurred at times. Although some behaviours can be clearly classified as nonacademic (e.g., sexual violence and physical assault), and others being easily named as academic misconduct (e.g., plagiarism), overlapping cases can occur, such as when one student bullies another into completing an assignment for them or allowing them to see their answers during a test. Even today, academic and non-academic misconduct remain entangled in some cases. In the early part of the twentieth century, it would seem that a "serious offence" in terms of student misconduct was left open to some interpretation.

\section{The Post-War-Pre-Internet Era: 1950-1991}

Notable large-scale developments in educational contexts, in both Canada and the United States, occurred after World War II. Although there were some parallels, the development of the two countries differed. The post WWW II period has been identified as a period of major educational development in Canada (Jones, 2014; Summerlee \& Christensen Hughes, 2010), though little is known specifically about how academic misconduct in Canada was handled during the early post-World War II years.

Educational administration emerged as a field of study in both countries during this time period. In the U.S. the first educational administration program was launched in 1950, with the financial support of the Kellogg Foundation (Gilbert et al., 1985). The same foundation also provided funding to the Canadian Education Association (CEA), two years later for Canada's first large scale project in educational leadership, which continued until 1956 (Gilbert et al., 1985). Near the end of that project, graduate programs in educational administration began to develop, with the University of Alberta being the first to admit students to a doctoral program in educational administration in 1957, conferring its first degrees a year later (Robertson, 1971). Other programs were simultaneously under development at the University of British Columbia and the University of Toronto, with the Ontario Institute for Studies in Education (OISE) at the University of Toronto being launched in 1965 (Gilbert et al., 1985). The University of Manitoba followed not long after. The Council of Ministers of Education, Canada (CMEC) was established in 1968 by provincial ministers of education, becoming "the only framework providing departments of education with an opportunity to work collectively" (CMEC, 2001, p. 8). 
In the United States, William (Bill) Bowers $(1964,1966)$ conducted the first largescale research on academic misconduct in the early 1960s, surveying more than 600 academic deans, over 500 student body presidents, and more than 5400 students at 99 American colleges. No similar large-scale research would be undertaken at Canadian institutions until decades later; but that is not to say that Canadian scholars were not interested in academic misconduct. One of the earliest known published papers by a Canadian scholar on academic dishonesty appeared in 1971. Written by Professor R.G. Martin (1971), from the University of Alberta, "Plagiarism and originality: Some remedies" was published in the May edition of The English Journal, an American publication.

The reasons why Martin did not publish his article in Canada are unknown, but it may have been partly due to the fact that there were few journals available to Canadian scholars wanting to write about academic integrity at that time. One of the first Canadian education journals was launched under the title of "Stoa" in April 1971, the publication later evolved into the Canadian Journal of Higher Education (CJHE), which addresses topics of interest in higher education. Martin's article discussed plagiarism as a general problem, with an implied focus on secondary schools, therefore it would not have been a good fit for the journal. The Canadian Journal of Education (CJE) would not be launched until five years later in 1976.

The 1960s and 1970s were a time of significant change in society and, by extension, in educational contexts. During this period of social unrest, campuses became host to student protests and the rules that had been infused into educational systems from kindergarten through to university came under scrutiny (Eerkes, 2010; Gilbert et al., 1985). In Canada, this was also the period when the professionalization of education began to advance, with teacher training moving out of teachers' colleges and into universities, a transition that was all but complete by the end of the 1970s (Gilbert, 1985).

The Constitution Act, 1982 succeeded the British North America Act (1867), when Canada's constitution was patriated from the United Kingdom, giving Canada the authority to amend its own constitution and act with sovereignty as an independent country. The Constitution Act, 1982, reaffirmed education in Canada as being primarily the responsibility of the provinces and territories, with the exceptions noted earlier (CMEC, 2001). Over time, there have been various reorganizations of provincial and territorial government ministries and departments concerning education. Some provinces have a single ministry or department responsible for education at all levels, whereas others have separate government units responsible for K-12 and advanced education. The organization of these ministries and departments can change over time, and such reorganizations are entirely within the purview of the provincial governments.

The 1980s included a period of fiscal restraint at all levels of education, following the financial boom of the 1970s. Changes in the global economy in the 1980s led to drastic changes in financial investments in education in a number of countries including Canada, the US, Australia, and the UK, among others (Eaton, 2009). In Canada, this resulted in the merging of government departments to reduce the administrative costs of education (CMEC, 2001). It also led to the development 
of cost-recovery educational programs in the 1980s, which morphed into revenuegenerating programs in the 1990s (Eaton, 2009). International student enrollments in higher education and the establishment of revenue-generating programs, including those offering English as an Additional Language, became lucrative (Eaton, 2009). As an example, the population of EAL students in the province of British Columbia increased " $334 \%$ from 1986 to 1995" (Nolan, 2001, p. 3). Such increases were common across the country as international student enrollments and English as an Additional Language (EAL) programs became a major source of income for Canadian higher education institutions (Eaton, 2009).

\section{The Creative Disruption Era: 1992-2019}

The financial restraint of the 1980s led to concerns about the commodification of education as governments systematically reduced their investment in education (Eaton, 2009). Concurrently, concerns about plagiarism and academic misconduct in Canadian higher education became more prominent (Hexham, 1992). Scholars across the world, including Canadians, have noted that there has been a correlative relationship between the commodification of education and the neoliberal university with a corresponding increase in concerns about academic misconduct (Eaton, 2021; Hersey \& Lancaster, 2015; Kleinman, 2016; Saltmarsh, 2005; Whiteman \& Gordon, 2001). In this section, we outline how the period of 1992-2019 was significant in terms of the development of academic integrity in Canadian education. Much of what is known about research on academic integrity in Canada during this period has been documented elsewhere (see Eaton \& Edino, 2018; Eaton et al., 2019), so instead, we bring forward new insights about this influential period that supplement existing work and provide deeper insights.

1992 was a watershed year for education and for academic integrity, in particular. The term "creative disruption" was coined in 1992 by Jean-Marie Dru in France (Nora, 2016). Although the phrase refers to creative and radical innovation in business (Nora, 2016), the concept is easily transferred to educational contexts (Eaton, 2021c). Although the genesis of the Internet had begun years before, the infrastructure behind the World Wide Web flourished around this time, with the first websites coming into existence during this period of rapid innovation. In 1992, the online service askERIC was launched by the Education Resources Information Center (ERIC) in the U.S. (Sutton, 2001). Although ERIC was launched in the 1960s as a bibliographic archive, the service's adoption of the Internet as a means to share knowledge led to it becoming a "pioneering e-mail-based question-answer service" (Sutton, 2001, p. 21) and ERIC became one of the first 100 websites ever launched (Sutton, 2001). In doing so, the service democratized knowledge and disseminated content in ways previously unknown in education (Eaton, 2021c).

At the time, those who had worked on the development of the technology that evolved into the Internet had never anticipated that those who used it might do for nefarious reasons (Kleinrock, 2009, 2019). As one of its developers pointed out, 
the strengths of Internet technology are simultaneously its weaknesses, which have included unethical use of information, plagiarism, and misappropriation of others' creations (Kleinrock, 2009). When services such as AskERIC were being launched in 1992, those who developed the Internet noted that they "did not anticipate that the dark side of the internet would emerge with such ferocity" (Kleinrock, 2019, n.p.).

However, the signs were there. One Canadian professor in particular became vocal about academic misconduct in the early 1990s, using the Internet to sound the alarm. Dr. Irving Hexham from the University of Calgary posted at length on electronic bulletin boards and informally on his web site about the need to address plagiarism in higher education (Hexham, 1992). Although his contributions were not peer reviewed, they nevertheless stand as influential and authoritative scholarly discussions of plagiarism with numerous citations (Eaton \& Edino, 2018).

As Hexham was making his views known in Canada and beyond, major developments relating to academic integrity were underway in the United States. Donald (Don) McCabe and colleagues established the Center for Academic Integrity (CAI) in 1992 (Fishman, 2016). McCabe's work built on that of Bowers (1964, 1966) and by the early 1990s, McCabe had identified a need for a large-scale initiative to address academic integrity in the US. Although the CAI was not explicitly established in response to the popularization of the Internet, the timing of its launch cannot be overlooked, as it coincided with major technological developments in education globally and also became its own form of creative disruption for academic integrity, as it was the first organized initiative to address breaches of academic integrity on a large scale. Due in a large part to McCabe's vision, the centre went on to include members from other countries, eventually changing its name to the International Center for Academic Integrity (ICAI) in 2010.

In 1999, the centre released its first iteration of the Fundamental Values of Academic Integrity, identifying five fundamental values to guide student conduct: fairness, honesty, respect, responsibility, and trust (ICAI, 2018). The document was later updated to include the sixth value of courage. Now in its third edition, (ICAI, 2021), this resource has provided the basis for dialogue, policy, and process in numerous countries, including Canada.

One of McCabe's areas of interest was the efficacy of honour codes, in both traditional and modified forms. Key components of traditional honour code systems include an orientation pledge, a commitment to report on the questionable behaviour of peers, and a student-run adjudication body to address misconduct. Later in his career, McCabe acknowledged that even if an institution calls itself an honour code school, without the necessary systems and support in place, a culture of honour may not actually exist (McCabe, Butterfield, \& Treviño, 2012). Conversely, a school can have a culture of honour even if they do not have an explicit honour code (Fishman, 2016; McCabe et al., 2012). An honour culture, without explicit honour codes, is arguably what has existed in Canada, where honour code schools have never been the norm. It is our position that it does not make sense for Canadian schools to try and emulate the American academic honour system, given historical differences between our two counties. That being said, orientation programs in which students commit to approaching their work with integrity can serve a symbolic purpose as 
part of a comprehensive institutional approach to academic integrity. This argument is substantiated by Christensen Hughes \& McCabe (2006a) who noted that although much can be learned from the American context with regards to academic integrity, there is a low likelihood that formal honour codes would be effective in Canada. Instead, Canadian schools have adopted a more multi-stakeholder approach, focusing not only on student conduct, but also on ethical conduct pertaining to all members of the academic community.

Systematic inquiry into academic integrity began to emerge in Canada in the 1990s, among both scholars and professional staff at universities. A few studies were published in the 1990s about academic integrity in Canada, laying the foundation for a proliferation of work after the turn of the millennium (see Genereux \& McLeod, 1995; Lytton, 1996; Woods, 1998). In parallel, student affairs professionals began addressing academic integrity at events such as the Canadian Conference on Student Judicial Affairs in 1998 (Eerkes, 2010; McKenzie, 2018).

The groundwork laid in the 1990s led to major developments in academic integrity in the first decade of the twenty-first century. In a four-page exposé in University Affairs (a periodical dedicated to university topics in Canada) Mullens (2000) summarized a number of academic misconduct cases at universities across the country, including cases of Internet-based essay mills, which we now refer to as contract cheating. Mullens's article was a pre-cursor to the seminal papers by Christensen Hughes and McCabe. (2006a, b), the second of which was awarded with the Canadian Society for Studies in Higher Education Sheffield Award for best paper in 2007 (CSSHE, n.d.). We have elaborated on this work in Chapter 3 (see Christensen Hughes \& Eaton, 2022).

Christensen Hughes and McCabe's (2006b) first contribution, based on predominantly US data, concluded that "the majority of undergraduate students [surveyed] have engaged in some type of misconduct in the completion of their academic work" while also agreeing that "such behaviour is morally wrong" (p. 52). Explanations for why students might engage in such behaviours regardless of their moral view, included a number of personal or demographic factors, such as "maturity, habit, attitude, culture and first language" (p. 53). Institutional factors were also identified; those that discouraged academic misconduct increased student risk-reward perception. Christensen Hughes and McCabe (2006a) observed:

Higher education plays an essential role in democratic society - one that requires U.S. [sic] to provide our students with a high quality education, to develop moral and engaged citizens, and to uphold the highest standards of integrity. We need a total recommitment to this role. (p. 59)

They concluded by calling for a comprehensive Canadian study, one that would help to identify "the unique characteristics of the Canadian higher education system" in order to tailor "institutional strategies appropriate for promoting academic integrity" as well as "to identify how Canadian colleges and universities are responding to academic misconduct when it does occur and what strategies have proven most successful" (Christensen Hughes and McCabe, 2006b, p. 59). 
The second article responded to this call, presenting the results of a study involving 11 Canadian higher education institutions, from five provinces, conducted between January 2002 and March 2003. Undergraduate and graduate students, teaching assistants and faculty, were surveyed about their perceptions and behaviours using a modified version of the survey developed by McCabe and colleagues via the Center of Academic Integrity's Assessment Project (Christensen Hughes and McCabe, 2006a). Given the methodological limitations of the study, the authors clearly advised, "the findings of this study should not be used to make definitive claims about the state of academic misconduct within Canada, but rather as indicators of potential areas of concern and action" (Christensen Hughes and McCabe, 2006a, p. 7).

The study concluded that "large numbers of Canadian high school, undergraduate and graduate students report they have engaged in a variety of questionable behaviours in the completion of their academic work" (Christensen Hughes \& McCabe, 2006a, p. 17) and that "consistent with the view of over $40 \%$ of faculty and TAs: cheating may be a serious problem in Canadian higher education" (p. 18). The study also identified substantial differences between student and faculty "beliefs about what constitutes academic misconduct". The authors suggested that the reason many students reported engaging in "unauthorized collaboration and falsification and fabrication behaviours" may be "simply because they don't believe they are wrong" (p. 18).

The authors recommended that Canadian institutions should take a number of actions, including "recommit[ting] to academic integrity" and investigating "where existing policies are failing" (Christensen Hughes \& McCabe, 2006a, p. 17). More specifically they observed, "New policies and procedures (including meaningful penalties) that have the confidence of the community are clearly needed...supported by system-wide educational efforts directed at administrators, faculty, TAs and students" (p. 17). They also called for increasing the quality of the educational experience, including assessment procedures.

With respect to honour codes - and in particular the expectation that students report on others' unethical actions-results from the seminal study conducted by Christensen Hughes and McCabe (2006a) suggest that honour codes would likely be ineffective in Canada. From the high school survey (first year students reflecting on their time in high school), "only $13 \%$ thought it likely or very likely that a student would report an incident of cheating" (p. 8). The percentage was the same for undergraduate students. For graduate students the percentage was only slightly higher $(18 \%)$. Once we consider the historical factors about how the Canadian and American higher education systems developed differently, the case for honour codes in Canada becomes even weaker.

The press took notice of the results of Christensen Hughes's and McCabe's study. What followed was a provocative treatment of academic misconduct in Canada (see Christensen Hughes \& Eaton, 2022). As one example, MacLean's, a national Canadian magazine, was somewhat misleading when it proclaimed on the front cover of its February 9, 2007 issue: "Fraud U. With more than half of Canadian university students cheating, all degrees are tainted. It's a national scandal. Why aren't schools doing more about it?" (MacLean's, 2007a). 
Not only did this issue feature a full length article (Gulli et al., 2007), but the editors focused their comments on the topic as well, chastising administrators for certifying graduates who had not fully earned their degrees (MacLean's, 2007a, p. 4):

We need to be able to trust our universities...but the fact is that few of them are moving swiftly to correct their cheating problems. Offences are observed and ignored. Processes developed to deal with culprits are bypassed. Punishments, on the infrequent occasions they are imposed, tend to be light. Simple methods of examination proven to prohibit cheating are inexplicably out of use. Universities have to do better, for their own sake, and for the sake of all who rely upon their certificates... There's a lot at stake.

The public responded with letters to the editor but university administrators and higher educational institutions were largely silent, leading the editors to further proclaim in the February 19th, 2007 issue, "go ahead and cheat" (MacLean's, 2007b, p. 2).

The February 26th issue featured a follow up article, on Maclean's attempt to get presidents and principals of leading research-intensive universities to comment on the findings. While few agreed to participate, those that did questioned the "prevalence of misconduct among their own students" as well as the extent to which universities were to blame (Gulli, 2007, p. 41). Instead, they suggested a range of factors were in play, including reduced government funding and increasing student/faculty ratios; the influence of parents, and primary and high school experiences; the Internet; and increasing competition for jobs.

Following, a number of universities began to take action, revisiting and revising their policies and practices, holding workshops, enhancing academic integrity resources and supports, and declaring "integrity weeks" in an effort to raise awareness. Some also made the results of their own investigations public, posting student survey results on their websites.

Other notable initiatives were also underway at this time. For example, the first federally-funded research projects relating to academic integrity were funded in this decade, supported by grants from the Social Sciences and Humanities Research Council of Canada (SSHRC), such as the one led by Lynn Taylor, University of Manitoba, who was awarded three grants totaling almost \$80,000 CAD over three years ( $\$ 35,785$ in 2002; $\$ 22,892$ in 2003; and $\$ 21,116$ in 2004) (SSHRC, n.d.). This funded research project led to publications and paved the way for future research (Paterson et al., 2003; Taylor et al., 2004).

Perhaps one of the most sustained outcomes of Taylor's work was the mentorship of a graduate student, Brandy Usick (2005), who later went on to lead institutional, regional and national initiatives, such as the co-founding of the country's first and only professional and scholarly journal on the topic, Canadian Perspectives on Academic Integrity (Usick, 2018). In addition, Usick has been acknowledged as a prominent knowledge keeper for academic integrity in Canadian higher education (Eaton, 2021a; McKenzie, 2018).The first decade of the 2000s was also pivotal for Canada in terms of how text-matching software (e.g., Turnitin®) was used in this country. In a landmark legal case, a student from McGill University, Jesse Rosenfeld, took the university to court over the use of Turnitin during the 2003-2004 academic year (Strawczynski, 2004). Rosenfeld challenged the university on its use 
of Turnitin ${ }^{\circledR}$, after he refused to submit his final semester assignment to Turnitin ${ }^{\circledR}$ and received a failing grade for doing so. The details of the case have been published elsewhere (see Strawczynski, 2004), but the key takeaway is that the courts found in favour of the student. The results of this case set a legal precedent in Canada regarding the use of text-matching software in Canada, with the long-term impact being that such software is not used in Canada to the extent that it is in other countries. There has also been limited research into how text-matching software is used in Canadian universities (for one example see Zaza \& McKenzie, 2018) in part because universities have firmly limited their use of these products or declined to use them all together.

The decade that followed the publication of Christensen Hughes and McCabe's articles, from 2007-2017, was when practitioners began connecting with one another in more organized and systematic ways. Educational developers from across the country participated in events during the annual conference of the Society for Teaching and Learning in Higher Education (STLHE), sharing their results and comparing strategies for addressing them. The Academic Integrity Council of Ontario (AICO) was founded in 2008 and the Canadian Consortium became an official branch of the International Center for Academic Integrity in 2014 (McKenzie, 2018). Amanda McKenzie, from the University of Waterloo, was the first representative of a Canadian university to join the board of directors of ICAI. Also during this time, small symposia were held in Alberta and British Columbia, as individuals from multiple institutions began to collaborate more intentionally (McKenzie, 2018).

These early efforts laid the foundation for more intensive multi-institutional, crossprovincial, and national-level collaborations that began to emerge in 2018, the first of which was a national-level policy analysis designed to examine how contract cheating was addressed in Canadian higher education institutional policies (see Eaton, 2019). The project was modelled after policy research conducted in Australia (see Bretag et al., 2011a, b) and the project lead for the Australia project, Tracey Bretag, mentored the lead for the Canadian project, Sarah Elaine Eaton, offering influential advice, such as dividing the project into smaller chunks (e.g., focused on different regions of the country) and engaging individuals from each region to take part so as to build capacity across the country. The project has resulted in multiple collaborative conference presentations and publications in the phases covering Western Canada and Ontario (see: Eaton, 2019a; McKenzie et al., 2020; Stoesz et al., 2019; Stoesz \& Eaton, 2020). At the time of this writing the analysis of policies at Atlantic Canadian universities is underway (see Eaton et al., 2021).

Through the mentoring of this project, Bretag and Eaton developed a professional relationship that resulted in Bretag being invited to the University of Calgary as a short-term visiting scholar in 2019. The visit evolved into a full-scale national symposium, with more than 150 participants coming from across the country, as well as from Great Britain (Canadian Symposium on Academic Integrity, 2019; Eaton, 2019c; University of Calgary, 2019). The inaugural Canadian Symposium on Academic Integrity hosted by the University of Calgary was described as a landmark event in Canadian higher education by multiple individuals (R. Mackay, 
personal communication to S. Eaton, April 18, 2019; T. Lancaster, personal communication to S. Eaton, December 3, 2019). This first national symposium on academic integrity brought together practitioners, educators, scholars, and leaders on a scale never before achieved in Canada. The symposium served as a launching point for the establishment of provincial academic integrity networks in British Columbia, Alberta, and Manitoba. Upon reflection, although the inaugural Canadian Symposium on Academic Integrity was not intended to serve as the culminating event of this era, that is arguably what happened. The years from 1992 to 2019 were ones of great advances in technology, education, and academic integrity; this was the era when creative disruption would characterize significant changes in education, business, and society in general. The arrival of the COVID-19 virus the following year brought with it a new era for society and education across the globe.

\section{0 and Beyond: Current Trends and Future Directions}

In 2020, the COVID-19 coronavirus pandemic changed the world. The impact on academic integrity was notable across education globally, including in Canada. Perspectives of Canadians regarding academic integrity during the pandemic were captured in a special issue of Canadian Perspectives on Academic Integrity, which included more than twenty contributions from authors across the country (Bens, 2020; Denham, 2020; Eaton, 2020; Gagné, 2020; Gedajlovic \& Wielemaker, 2020; Gervais, 2020; Kier, 2020; McKenzie, 2020; Miron, 2020; Nearing, 2020; Rahimian, 2020; Rovere, 2020; Scurr, 2020; Seeland, 2020; Sopcak, 2020; Stoesz, 2020; Teymouri \& Boisvert, 2020; Thacker, 2020; Vogt, 2020; Wheatley, 2020; Wolsky \& Hamilton, 2020). The issue, which received international acclaim (see Brown, 2021), was one of the only formal endeavours anywhere in the world to capture the experiences of those working in academic integrity during the first year of the COVID-19 pandemic.

Also in 2020, Canadians took on international leadership roles, with Jennie Miron of Humber College leading the International Day of Action Against Contract Cheating (Miron, 2020) and Sarah Elaine Eaton being named as the Editor-in-Chief of the International Journal for Educational Integrity, after the passing of Tracey Bretag, the Australian who co-founded the journal in 2005.

With the publication of this book, we can see that much has changed since Christensen Hughes and McCabe (2006a, b) published their two seminal articles on academic misconduct in Canada, fifteen years prior. In particular, since 2018, multiinstitutional research has become the norm in Canada in both official languages of English and French. For examples of research led by Francophone scholars (published in English) see Peters and Cadieux (2019), and Peters et al. (2019, 2022).

In addition, since about 2020 Indigenous scholars have been contributing more to the knowledge base of academic integrity, showing how Indigenous ways of being, knowing, learning, and teaching are fundamentally ethical, and exist in parallel to western interpretations of values associated with academic integrity (e.g., Maracle, 2020; Gladue, 2021a, b; Lindstrom, 2022; Poitras Pratt \& Gladue, 2022). 
The research, resources and efforts of Canadians detailed in this chapter showcase contributions from our country that simultaneously align with internationally recognized values and approaches, while highlighting contributions and perspectives that are uniquely Canadian. We, in Canada, have become global leaders in academic integrity, with researchers, administrators, and practitioners collaborating regularly and intentionally with colleagues across the country and across the world.

However, much work remains to be done. There remains a need for enhanced support for this important work. National funding agencies must value academic integrity research and support that work with increased funding for research. There are few formal educational or professional development training programs available in Canada for practitioners and future scholars of academic integrity. Universities and colleges need more programs to train academic integrity professionals, scholars, and administrators. Ministries of education and advanced education, along with provincial and territorial quality assurance agencies and national organizing bodies for higher education, have yet to make academic integrity a priority. And as yet, there is no legislation in Canada against contract cheating companies. As Kenny and Eaton (2022) point out in this volume, much of the work relating to academic integrity is invisible and unrecognized. There is an urgent need for more Canadian postsecondary institutions to establish centralized offices of academic integrity on their campuses, with positions that are funded from regular operating budgets, rather than "soft" or project-based funding.

These gaps offer a clear direction for future opportunities and priorities. In particular, advocating for provincial and national bodies to actively recognize the importance of academic integrity in our educational systems remains a priority. Similarly, if Canada is to be successful in enacting legislation against contact cheating companies, then efforts must continue to be coordinated and sustained over time (Eaton, 2021b). This is the work of academic integrity professionals, administrators, and scholars moving forward. Canadians are poised to continue making significant and substantive contributions to the field of academic integrity, but their efforts must be sustained and supported by senior educational leaders, policy makers, and funders. The integrity of the degrees we confer and the confidence Canadians have in our higher education institutions, depends on it.

\section{References}

Allmendinger, D. (1973). The Dangers of Ante-Bellum Student Life. Journal of Social History, 7(1), 75. https://doi.org/10.1353/jsh/7.1.75

Angulo, A. J. (2016). Diploma mills: How for-profit colleges stiffed students, taxpayers and the American dream. Johns Hopkins University Press.

Bens, S. (2020). A reflection on change and academic integrity during COVID-19. Canadian Perspectives on Academic Integrity, 3(2), 11-13. https://doi.org/10.11575/cpai.v3i2.71637

Bertram Gallant, T. (2008). Academic integrity in the twenty-first century: A teaching and learning imperative. Wiley. 
Bowers, W. J. (1964). Student dishonesty and its control in college. NY: Bureau of Applied Social Research, Columbia University.

Bowers, W. J. (1966). Student dishonesty and its control in college. (Doctor of Philosophy). Columbia University.

Bretag, T., Mahmud, S., East, J., Green, M., \& James, C. (2011). Academic integrity standards: A preliminary analysis of the academic integrity policies at Australian Universities. Paper presented at the Proceedings of AuQF 2011 Demonstrating Quality.

Bretag, T., Mahmud, S., Wallace, M., Walker, R., James, C., Green, M., \& Partridge, L. (2011). Core elements of exemplary academic integrity policy in Australian higher education. International Journal for Educational Integrity, 7(2), 3-12. https://doi.org/10.21913/IJEI.v7i2.759

Brown, J. F. (2021). Journal issue spotlight: Canadian perspectives on academic integrity during Covid-19. https://www.academicintegrity.org/integrity/journal-issue-spotlight-canadianperspectives-on-academic-integrity-during-covid-19/

Cameron, D. M. (1991). More than an academic question: Universities, government, and public policy in Canada. Institute for Research on Public Policy.

Canadian Symposium on Academic Integrity: Program and Abstracts. (2019). In S. E. Eaton, J. Lock, \& M. Schroeder (Eds.). University of Calgary. http://hdl.handle.net/1880/110293

Canadian Society for the Study of Higher Education / Société canadienne pour l'étude de l'enseignement supérieur. (n.d.). CJHE Sheffield Award. https://csshe-scees.ca/awards/cjhe-she ffield-award/

Canadian Society for the Study of Higher Education/Société canadienne pour l'étude de l'enseignement supérieur. (2020). 2020-2025 Strategic Plan. https://csshescees.files.wordpress. com/2020/06/csshe_strategicplan2019_final_may2020_e.pdf

Christensen Hughes, J., \& Eaton, S. E. (2022). Student integrity violations in the academy: More than a decade of growing complexity and concern. In S. E. Eaton \& J. Christensen Hughes (Eds.), Academic integrity in Canada: An enduring and essential challenge, Springer.

Christensen Hughes, J. M., \& McCabe, D. L. (2006). Academic misconduct within higher education in Canada. The Canadian Journal of Higher Education, 36(2), 1-21. http://journals.sfu.ca/cjhe/ index.php/cjhe/article/view/183537/183482

Christensen Hughes, J. M., \& McCabe, D. L. (2006). Understanding academic misconduct. Canadian Journal of Higher Education, 36(1), 49-63. https://journals.sfu.ca/cjhe/index.php/cjhe/art icle/view/183525

Colleges Ontario. (2019). About. https://www.collegesontario.org/en

Colleges \& Institutes Canada. (n.d.). https://www.collegesinstitutes.ca/

Council of Ministers of Education (CMEC) Canada. (2001). The development of education in Canada. https://www.cmec.ca/Publications/Lists/Publications/Attachments/34/ice46devca.en.pdf

Council of Ministers of Education Canada (CMEC). (2020). Education in Canada: An overview. https://www.cmec.ca/299/Education-in-Canada-An-Overview/index.html

Council of Ontario Universities. (2019). Mission. https://cou.ca/about/mission/

Denham, T. (2020). My work in academic integrity 2020: Not all I hoped it would be. Canadian Perspectives on Academic Integrity, 3(2), 14-15. https://doi.org/10.11575/cpai.v3i2.71641

Eaton, S. E. (2009). Marketing of revenue-generating ESL programs at the University of Calgary: A qualitative study. Doctoral thesis, University of Calgary.

Eaton, S. E. (2019a). Contract cheating in Canada: National Policy Analysis. https://osf.io/n9kwt/

Eaton, S. E. (2019b). Overview of higher education in Canada. In J. M. Jacob \& R. Heydon (Eds.), Bloomsbury Education and Childhood Studies. Bloomsbury.

Eaton, S. E. (2019c). Reflections on the 2019 Canadian symposium on academic integrity. Canadian Perspectives on Academic Integrity, 2(2), 1-6. https://doi.org/10.11575/cpai.v2i2.69454

Eaton, S. E. (2020). Academic integrity in 2020: Year in review. Canadian Perspectives on Academic Integrity, 3(2). https://doi.org/10.11575/cpai.v3i2.71636

Eaton, S. E. (2021a). Building collaborative networks to support academic integrity. Keynote address presented at the Academic Integrity Inter-Institutional Meeting (AIIIM) 2021. Online. 
Eaton, S. E. (2021b). Plagiarism in higher education: Tackling tough topics in academic integrity. Santa Barbara, CA: Libraries Unlimited.

Eaton, S. E. (2022). Contract cheating in Canada: A comprehensive overview. In S. E. Eaton \& J. Christensen Hughes (Eds.), Academic integrity in Canada: An enduring and essential challenge, Springer.

Eaton, S. E., \& Edino, R. I. (2018). Strengthening the research agenda of educational integrity in Canada: A review of the research literature and call to action. International Journal of Educational Integrity, 14(1). https://doi.org/10.1007/s40979-018-0028-7

Eaton, S. E., Crossman, K., \& Edino, R. I. (2019). Academic integrity in Canada: An Annotated Bibliography. http://hdl.handle.net/1880/110130

Eaton, S. E., Stoesz, B. M., Godfrey Anderson, J. R., \& LeBlanc-Haley, J. (2021). Contract Cheating in Canada, National Policy Analysis-Phase Four, Atlantic Canada: Research Project Brief. http:// hdl.handle.net/1880/113110

Eerkes, D. (2010). Student judicial affairs and academic integrity. In D. G. Hardy Cox \& C. C. Strange (Eds.), Achieving student success: Effective student services in Canadian higher education (pp. 100-111). Montreal: McGill-Queen's University Press.

Féderacion des cégeps. (n.d). https://www.cegepsquebec.ca/en/

Fishman, T. (2016). Academic integrity as an educational concept, concern, and movement in US institutions of higher learning. In T. Bretag (Ed.), Handbook of Academic Integrity (pp. 7-21). Springer.

Gagné, A. (2020). Reflections on academic integrity and educational development during COVID19. Canadian Perspectives on Academic Integrity, 3(2), 16-17. https://doi.org/10.11575/cpai. v3i2.71642

Gedajlovic, E., \& Wielemaker, M. (2020). Neither abuse, nor neglect: A duty of care perspective on academic integrity. Canadian Perspectives on Academic Integrity, 3(2), 63-69. https://doi.org/ 10.11575/cpai.v3i2.71655

Genereux, R. L., \& McLeod, B. A. (1995). Circumstances surrounding cheating: A questionnaire study of college students. Research in Higher Education, 36(6), 687-704. http://www.jstor.org/ stable/40196166

Gervais, L. (2020). Academic integrity and student support during COVID-19. Canadian Perspectives on Academic Integrity, 3(2). https://doi.org/10.11575/cpai.v3i2.71528

Gilbert, V. K., Sheehan, A. T., \& Teeter, K. G. (1985). In loco parentis: A teacher's guide to educational administration. University of Toronto.

Gladue, K. (2021a). Indigenous academic integrity. Calgary: University of Calgary. https://taylor institute.ucalgary.ca/resources/indigenous-academic-integrity

Gladue, K. (2021b). Indigenous academic integrity: Paradigms into practice. Paper presented at the International Center for Academic Integrity (ICAI) Annual Conference (online).

Gulli, C. (2007, February 24). Cheating? Who us? Maclean's Magazine, 120(7), 41-41.

Gulli, C., Köhler, N., \& Patriquin, M. (2007, February 12). The great university cheating scandal. Maclean's Magazine. 32-36. https://archive.macleans.ca/issue/20070212

Harvard University. (2020). History. https://www.harvard.edu/about-harvard/harvard-glance/his tory

Hersey, C., \& Lancaster, T. (2015). The online industry of paper mills, contract cheating services, and auction sites. Paper presented at the Clute Institute International Education Conference. https://www.researchgate.net/publication/280830577_The_Online_Industry_ of_Paper_Mills_Contract_Cheating_Services_and_Auction_Sites

Hexham, I. (1992). On plagiarism and integrity in scholarly activity. Humanist: Humanities Computing, 5(4). http://dhhumanist.org/Archives/Virginia/v05/0795.html

International Center for Academic Integrity (ICAI). (2021). The fundamental values of academic integrity (3rd ed.). https://www.academicintegrity.org/fundamental-values/

International Center for Academic Integrity (ICAI). (2018). About. https://web.archive.org/web/ 20180318234929/.php http://www.academicintegrity.org:80/icai/about-3.php 
Jones, G. A. (2014). An introduction to higher education in Canada. In K. M. Joshi \& S. Paivandi (Eds.), Higher education across nations (Vol. 1, pp. 1-38). B.R. Publishing.

Kenny, N., \& Eaton, S. E. (2022). Academic integrity through a SoTL lens and 4M framework: An institutional self-study. In S. E. Eaton \& J. Christensen Hughes (Eds.), Academic integrity in Canada: An enduring and essential challenge, Springer.

Kier, C. A. (2020). Reflections on COVID-19 and academic integrity. Canadian Perspectives on Academic Integrity, 3(2), 20-22. https://doi.org/10.11575/cpai.v3i2.71643

Kleinman, D. L. (2016). From matters of integrity to cultural transformation: Higher education in the era of neoliberalism. In T. Bretag (Ed.), Handbook of Academic Integrity (pp. 929-941). Springer. https://doi.org/10.1007/978-981-287-098-8_29

Kleinrock, L. (2009, October 24). Leonard Kleinrock, Mr. Internet. Los Angeles Times. https:// www.latimes.com/opinion/la-oe-morrison-use24-2009oct24-story.html

Kleinrock, L. (2019, October 29). Opinion: 50 years ago, I helped invent the internet. How did it go so wrong? Los Angeles Times. https://www.latimes.com/opinion/story/2019-10-29/internet50th-anniversary-ucla-kleinrock

Lindstrom, G. (2022). Accountability, relationality and indigenous epistemology: Advancing an indigenous perspective on academic integrity. In S. E. Eaton \& J. Christensen Hughes (Eds.), Academic integrity in Canada: An enduring and essential challenge, Springer.

Lucas, C. J. (2006). American higher education: A history. Palgrave MacMillan.

Lytton, H. (1996). This is how it's always been done: The treatment of academic misconduct in Canada. The Canadian Journal of Sociology, 21(2), 223-235. https://doi.org/10.2307/3341978 https://doi.org/10.2307/3341978

MacLean's. (2007a, February 12). https://archive.macleans.ca/issue/20070212

MacLean's. (2007b, February 19). https://archive.macleans.ca/issue/20070219

Maracle, I. B. J. (2020). Seven grandfathers in academic integrity. https://studentlife.utoronto.ca/ wp-content/uploads/Seven_Grandfathers_in_Academic_Integrity.pdf

Maritime Provinces Higher Education Commission. (n.d.). About. http://www.mphec.ca/index.aspx

Martin, R. (1971). Plagiarism and originality: Some remedies. English Journal, 60(5), 621-628. https://doi.org/10.2307/813078

McCabe, D. L., Butterfield, K. D., \& Treviño, L. K. (2012). Cheating in college: Why students do it and what educators can do about it. Johns Hopkins University Press.

McKenzie, A. M. (2018). Academic integrity across the Canadian landscape. Canadian Perspectives on Academic Integrity, 1(2), 40-45. https://doi.org/10.11575/cpai.v1i2.54599.g42964

McKenzie, A. (2020). COVID-19: A silver lining for academic integrity from a pandemic. Canadian Perspectives on Academic Integrity, 3(2), 23-25. https://doi.org/10.11575/cpai.v3i2.71644

McKenzie, A., Miron, J. B., Devereaux, L., Eaton, S. E., Persaud, N., Rowbotham, K., \& Thacker, E. (2020, March 8). Contract cheating language within academic integrity policies in the university sector in Ontario, Canada. Paper presented at the International Center for Academic Integrity (ICAI) 2020 Conference.

Miron, J. B. (2020). International Day of Action (IDoA) against contract cheating 2020-Update from the chair of the IDoA planning committee. Canadian Perspectives on Academic Integrity, 3(2). https://doi.org/10.11575/cpai.v3i2.71473

Monohan, E. J. (1971). Some notes for an anecdotal history of Canadian universities STOA, 1(1). https://journals.sfu.ca/cjhe/index.php/cjhe/article/view/35/20530

Mullens, A. (2000). Cheating to win. University Affairs, 41(10), 22-28.

Nearing, E. (2020). Supporting the pivot online: Academic integrity initiatives at University of Waterloo. Canadian Perspectives on Academic Integrity, 3(2), 29-31. https://doi.org/10.11575/ cpai.v3i2.71645

Nolan, R. E. (2001). The power of theory in the administration of ESL programs. Adult Basic Education, 11(1), 3-17.

Nora, D. (2016, January 24). Le concept de "Disruption" expliqué par son créateur. L'Obs. https://www.nouvelobs.com/economie/20160122.OBS3214/le-concept-de-disrup tion-explique-par-son-createur.html 
Organisation for Economic Co-operation and Development/Organisation de Coopération et de Développement Economiques (OECD). (2020). Education at a Glance 2020: OECD Indicators. https://read.oecd-ilibrary.org/education/education-at-a-glance-2020_43439e03-en\#page1

Paterson, B., Taylor, L., \& Usick, B. (2003). The construction of plagiarism in a school of nursing. Learning in Health \& Social Care, 2(3), 147. https://doi.org/10.1046/j.1473-6861.2003.00047.x

Peters, M., \& Cadieux, A. (2019). Are Canadian professors teaching the skills and knowledge students need to prevent plagiarism? International Journal for Educational Integrity, 15(10). https://doi.org/10.1007/s40979-019-0047-z

Peters, M., Boies, T., \& Morin, S. (2019). Teaching academic integrity in Quebec universities: Roles professors adopt. Frontiers in Education, 4(99), 1-13.

Peters, M., Fontaine, S., \& Frenette, E. (2022). Teaching the teachers: To what extent do preservice teachers cheat on exams and plagiarise in their written work? In S. E. Eaton \& J. Christensen Hughes (Eds.), Academic integrity in Canada: An enduring and essential challenge, Springer.

Poitras Pratt, Y., \& Gladue, K. (2022). Re-defining academic integrity: Embracing indigenous truths. In S. E. Eaton \& J. Christensen Hughes (Eds.), Academic integrity in Canada: An enduring and essential challenge, Springer.

Rahimian, M. (2020). Academic integrity and the pandemic. Canadian Perspectives on Academic Integrity, 3(2), 32-35. https://doi.org/10.11575/cpai.v3i2.71666

Robertson, N. L. (1971). The doctorate education in Canada. Phi Delta Kappa.

Rovere, D. A. (2020). Reducing plagiarism and improving writing: A lesson from Chinese painting. Canadian Perspectives on Academic Integrity, 3(2), 57-62. https://doi.org/10.11575/cpai.v3i2. 71211

Royal Military College of Canada. (2016). About the Royal Military College of Canada. https:// www.rmc-cmr.ca/en/college-commandants-office/about-royal-military-college-canada

Saltmarsh, S. (2005). 'White pages' in the academy: Plagiarism, consumption and racist rationalities. International Journal for Educational Integrity, 1(1). https://doi.org/10.21913/IJEI.v1i1.17

Scurr, C. (2020). Reflections on academic integrity during COVID-19. Canadian Perspectives on Academic Integrity, 3(2), 36-38. https://doi.org/10.11575/cpai.v3i2.71647

Seeland, J. (2020). Reflection on academic integrity during COVID-19. Canadian Perspectives on Academic Integrity, 3(2), 39-40. https://doi.org/10.11575/cpai.v3i2.71648

Social Sciences and Humanities Research Council. (SSHRC). (n.d.). Award recipients. https://www. sshrc-crsh.gc.ca/results-resultats/recipients-recipiendaires/index-eng.aspx

Sopcak, P. (2020). Academic integrity and the pandemic. Canadian Perspectives on Academic Integrity, 3(2), 41-42. https://doi.org/10.11575/cpai.v3i2.71649

Statistics Canada. (2019). Postsecondary enrolments, by status of student in Canada, country of citizenship and sex. https://www150.statcan.gc.ca/t1/tbl1/en/tv.action?pid=3710008601

Statistics Canada. (2020). Education indicators in Canada. Retrieved October 2, 2020, from https:// www150.statcan.gc.ca/n1/daily-quotidien/200602/dq200602b-eng.htm

Stoesz, B. M. (2020). Educational challenges of 2020 and hope for 2021. Canadian Perspectives on Academic Integrity, 3(2), 43-44. https://doi.org/10.11575/cpai.v3i2.71635

Stoesz, B. M., \& Eaton, S. E. (2020). Academic integrity policies of publicly funded universities in western Canada. Educational Policy. https://doi.org/10.1177/0895904820983032

Stoesz, B. M., Eaton, S. E., Miron, J. B., \& Thacker, E. (2019) Academic integrity and contract cheating policy analysis of colleges in Ontario Canada. International Journal for Educational Integrity, 15(4), 1-18. https://doi.org/10.1007/s40979-019-0042-4

Strawczynski, J. (2004). When students won't Turnitin: An examination of the use of plagiarism prevention services in Canada. Education \& Law Journal, 14(2), 167-190.

Summerlee, A. J. S., \& Christensen Hughes, J. (2010). Pressures for change and the future of university education. Taking stock: Research on teaching and learning in higher education (pp. 243-260). McGill-Queen's University Press.

Sutton, S. A. (2001). Integrating 21 st century access to ERIC services and resources. Government Information Quarterly, 18(1), 19-30. https://doi.org/10.1016/S0740-624X(00)00063-0 
Taylor, K. L., Usick, B. L., \& Paterson, B. L. (2004). Understanding plagiarism: The intersection of personal, pedagogical, institutional, and social contexts. Journal on Excellence in College Teaching, 15(3), 153-174.

Teymouri, N., \& Boisvert, S. (2020). Reflections on COVID-19 and academic integrity. Canadian Perspectives on Academic Integrity, 3(2), 45-46. https://doi.org/10.11575/cpai.v3i2.71650

Thacker, E. J. (2020). Reflections from a novice academic integrity researcher during COVID-19. Canadian Perspectives on Academic Integrity, 3(2), 47-48. https://doi.org/10.11575/cpai.v3i2. 71651

Thacker, E. J., \& McKenzie, A. (2022). Using quality assurance frameworks to support an institutional culture of academic integrity at Canadian universities. In S. E. Eaton \& J. Christensen Hughes (Eds.), Academic integrity in Canada: An enduring and essential challenge, Springer.

Union of Ontario Indians. (2013). An overview of the Indian residential school system. http://www. anishinabek.ca/wp-content/uploads/2016/07/An-Overview-of-the-IRS-System-Booklet.pdf

University of Calgary. (2019). In Proceedings of Canadian Symposium on Academic Integrity (website). https://go.ucalgary.ca/Academic-Integrity.html

Universities Canada. (2019). Membership and governance. https://www.univcan.ca/fr/a-propos/adh esion-et-gouvernance/

Usick, B. L. (2005). Is plagiarism an issue in graduate education? An examination of two graduate programs. (MEd thesis). University of Manitoba. http://search.proquest.com/docview/305088 192/abstract

Usick, B. L. (2018). Editorial: Inaugural issue-Brandy Usick. Canadian Perspectives on Academic Integrity, 1(1). https://doi.org/10.11575/cpai.v1i1.43363

Vogt, L. (2020). My journey to becoming an academic integrity specialist. Canadian Perspectives on Academic Integrity, 3(2), 49-50. https://doi.org/10.11575/cpai.v3i2.71652

Wheatley, B. (2020). The COVID cloud's Ag lining. Canadian Perspectives on Academic Integrity, 3(1), 51-54. https://doi.org/10.11575/cpai.v3i2.71653

Whiteman, S. A., \& Gordon, J. L. (2001). Cross conversations: The price of an "A": An educator's responsibility to academic honesty. The English Journal, 91(2), 25-30. https://doi.org/10.2307/ 822339

Wolsky, K. L., \& Hamilton, M. J. (2020). Faculty development and academic integrity during pandemic times. Canadian Perspectives on Academic Integrity, 3(2), 55-56. https://doi.org/10. 11575/cpai.v3i2.71654

Woods, J. T. (1998). Academic integrity policies and practices in common law Canadian universities: An examination of compliance with natural justice. (Doctor of Philosophy). Bowling Green State University.

Zaza, C., \& McKenzie, A. (2018). Turnitin® Use at a Canadian university. Canadian Journal for the Scholarship of Teaching and Learning, 9(2). https://doi.org/10.5206/cjsotl-rcacea.2018.2.4

Sarah Elaine Eaton Ph.D., is an Associate Professor in the Werklund School of Education and the inaugural Educational Leader in Residence, Academic Integrity, University of Calgary. She is also the Editor-in-Chief of the International Journal for Educational Integrity and the author of Plagiarism in Higher Education: Tackling Tough Topics in Academic Integrity (Eaton, 2021). Her research focuses on ethics and integrity in higher education and she has led numerous research teams and the local and national levels. Eaton advocates for pro-active and multi-stakeholder approaches to upholding and enacting integrity throughout the academy.

Julia Christensen Hughes Ph.D., has long advocated for ensuring the highest standards of academic integrity in higher education-in teaching, research and administrative practice. Her article, Academic Misconduct within Higher Education in Canada, with the late Don McCabe (published in 2006, in the Canadian Journal of Higher Education), received the Sheffield Award for research excellence (2007), from the Canadian Society for Studies in Higher Education. As former and founding Dean of the Gordon S. Lang School of Business and Economics (2009-2019) 
at the University of Guelph, Julia was a champion of business ethics, corporate social responsibility and the need for business schools to be aligned with the UN's Sustainable Development Goals (SDG's). In her new role as President of Yorkville University, Julia is looking forward to supporting and enhancing the institution's long-standing commitment to integrity.

Open Access This chapter is licensed under the terms of the Creative Commons Attribution 4.0 International License (http://creativecommons.org/licenses/by/4.0/), which permits use, sharing, adaptation, distribution and reproduction in any medium or format, as long as you give appropriate credit to the original author(s) and the source, provide a link to the Creative Commons license and indicate if changes were made.

The images or other third party material in this chapter are included in the chapter's Creative Commons license, unless indicated otherwise in a credit line to the material. If material is not included in the chapter's Creative Commons license and your intended use is not permitted by statutory regulation or exceeds the permitted use, you will need to obtain permission directly from the copyright holder.

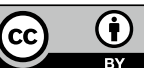

